\title{
Potential of biogas production to reduce firewood consumption in remote high-elevation Himalayan communities in Nepal
}

\author{
Thomas Gross $^{1, *}$, Alex Zahnd ${ }^{2,3}$, Suman Adhikari ${ }^{4}$, Abhishek Kaphre $^{5}$, Subodh Sharma ${ }^{4}$, Bivek Baral $^{4}$, \\ Sunil Kumar ${ }^{5}$, and Christoph Hugi ${ }^{1}$ \\ ${ }^{1}$ Institute for Ecopreneurship, University of Applied Sciences and Arts Northwestern Switzerland, Muttenz, Switzerland \\ ${ }^{2}$ Rural Integrated Development Service, RIDS-Switzerland, Reitnau, Switzerland \\ 3 Rural Integrated Development Service, RIDS-Nepal, Kathmandu, Nepal \\ ${ }^{4}$ Kathmandu University, Dhulikhel, Nepal \\ ${ }^{5}$ CSIR-NEERI, National Environmental Engineering and Research Institute, Nagpur, India
}

Received: 28 February 2017 / Received in final form: 21 July 2017 / Accepted: 27 July 2017

\begin{abstract}
Remote communities in the Nepalese mountains above $2500 \mathrm{~m}$ a.s.l. belong to the most precarious in the world. Inhabitants struggle for the minimum in terms of safe drinking water, food and sanitation. Reliable, affordable and clean energy for cooking, room heating and warm water for personal hygiene is often lacking and dependency on firewood very high. The remoteness and unlikeliness of electric grid connection in the coming decades make a diversified energy supply from renewable local resources crucial. Small-scale anaerobic digestion (AD) of organic substrates has been used for long in rural areas of developing countries to produce biogas as energy source and recover residue as organic fertilizer. AD is challenging at high elevations due to year around lower ambient temperatures and lower annual biomass production per area compared to lowlands. Nevertheless, examples of operational household AD exist even above $3000 \mathrm{~m}$ a.s.l. in the Andes. Here we compare firewood consumption with biogas potential from organic substrates in a community with 39 households at $3150 \mathrm{~m}$ a.s.l. in Jumla District, Nepal. In five households with varying numbers of members and animals kept, mean firewood use and its energy content per capita (cap) and day (d) were $2.1 \mathrm{~kg}$ or ca. $25 \mathrm{MJ}$ in spring and $2.3 \mathrm{~kg}$ or ca. $28 \mathrm{MJ}$ in winter. Easily available substrates include cow, sheep and horse dung from overnight shelters and human excrements from pit latrines, amounting on average to $1.7 \mathrm{~kg}$ wet weight $\left(\mathrm{kg}_{\mathrm{ww}}\right) \mathrm{cap}^{-1} \mathrm{~d}^{-1}$ in spring and $2.2 \mathrm{~kg}_{\mathrm{ww}} \mathrm{cap}^{-1} \mathrm{~d}^{-1}$ in winter. Adjusted to normal conditions $\left(\mathrm{Nm}^{3}\right.$ at $\left.0{ }^{\circ} \mathrm{C}, 1013.15 \mathrm{hPa}\right)$, these substrates yielded on average $0.08 \mathrm{Nm}^{3} \mathrm{cap}^{-1} \mathrm{~d}^{-1}$ biogas in spring and $0.12 \mathrm{Nm}^{3} \mathrm{cap}^{-1} \mathrm{~d}^{-1}$ in winter (35-60\% methane content) in biochemical methane potential (BMPs) tests at $36^{\circ} \mathrm{C}$. This could provide up to $60 \%$ of basic cooking needs on average and up to $75 \%$ in a "typical" household in terms of members and animals kept. Of the overall thermal energy needs including also room heating ca. $10-20 \%$ could be covered, substituting $0.1-0.4$ (mean: 0.2 ) $\mathrm{kg}_{\text {firewood cap }}{ }^{-1} \mathrm{~d}^{-1}$. If only animal dung and human excrements are considered, no competition for resources arises as residues can still be used as organic fertilizer. This study supports the design and introduction of planned pilot digesters integrated into on-going community development including pit latrines for substrate availability, greenhouses as possible way of thermal insulation, and planned pico-hydropower plants to use excess electricity during the night for digester heating.
\end{abstract}

\section{Introduction}

Firewood is the main cooking fuel in Nepal and used by $64 \%$ of all households, followed by liquid petroleum gas $(21 \%$ of households in Nepal), cow dung (10\%), biogas (2\%) and others $(3 \%)$ including kerosene and electricity [1]. In the mountain ecological belt ( $>2500 \mathrm{~m}$ a.s.l.) $95 \%$ of households depend on firewood as cooking fuel, less in the hill (500$2500 \mathrm{~m}$ a.s.l., $67 \%)$ and Terai (66-500m a.s.l., 57\%)

\footnotetext{
* e-mail: thomas.gross@fhnw.ch
}

ecological belts [1]. Traditional indoor burning on open fireplaces or inefficient indoor stoves has led to multiple and severe public health and environmental problems. As houses are poorly ventilated, inhabitants are exposed to mixtures of air pollutants including poisonous carbon monoxide $(\mathrm{CO})$ and particles below $2.5 \mu \mathrm{m}$ in diameter $\left(\mathrm{PM}_{2.5}[2]\right)$ which are connected with cataracts, cardiovascular issues as well as respiratory diseases and cancer[3]. Improved smokeless metal stoves (Fig. 1A) can reduce $\mathrm{PM}_{2.5}$ and $\mathrm{CO}$ concentrations to levels meeting national standards $[2,4]$ and reduce firewood consumption by $40-50 \%$ compared to open fireplaces (Zahnd, pers. comm.). Still ca. 15-20 kg of firewood 

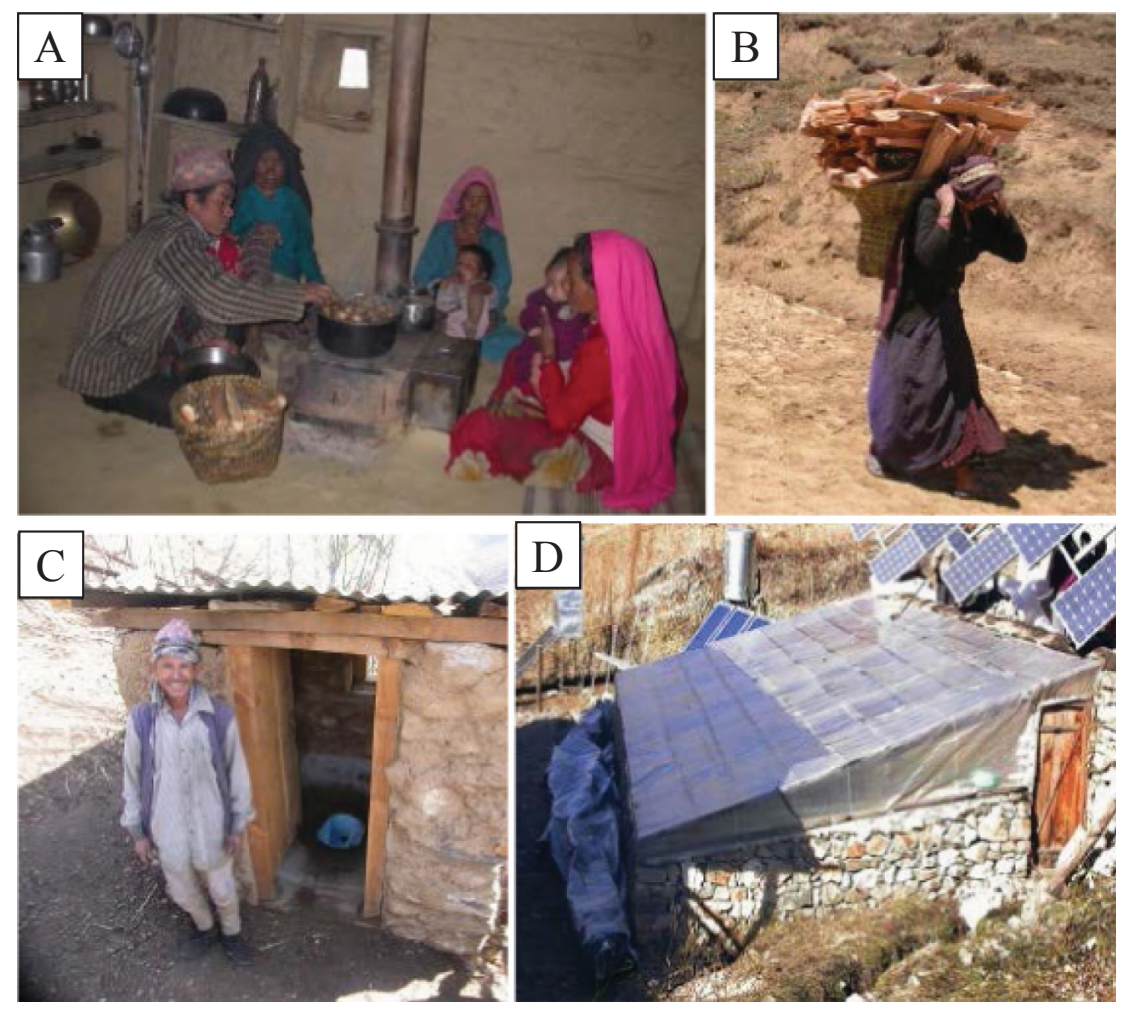

Fig. 1. (A) A living room with smokeless metal stove; (B) woman carrying firewood; (C) pit latrine; (D) local greenhouse, all @ A. Zahnd.

is required (Fig. 1B) per household and day (ca. $2-3 \mathrm{~kg}$ per capita and day) for basic thermal energy requirements and mainly collected by women and girls who spend $2-5$ hours per day, depending on the local level of deforestation (Zahnd, pers. comm.).

A possible alternative is biogas produced from organic substrates through anaerobic digestion (AD). Methane $\left(\mathrm{CH}_{4}\right)$ is the primary energy carrier in biogas with a higher heating value of ca. $38 \mathrm{MJ} \mathrm{Nm}^{-3} \mathrm{CH}_{4}$ and constitutes ca. $50-75 \%$ of its volume[5]. AD is widely practiced in developing countries including Nepal, India and China [6$8]$ as energy source, organic waste treatment option and for fertilizer properties of the solid-liquid residue or slurry [9]. It is most common in warm rural contexts due to substrate availability such as animal manure and favourable ambient temperatures for fast microbial degradation at a mesophilic temperature range $\left(20-40^{\circ} \mathrm{C}\right)$ without heating [10]. If sufficient substrate is available, $\mathrm{AD}$ is possible in colder climates via heating or psychrophilic $\mathrm{AD}$ below $20^{\circ} \mathrm{C}$. Both ways require thermal insulation and at lower temperatures digester volume has to be increased to compensate slower microbial degradation by higher hydraulic retention times [11], affecting economic feasibility. Only few studies on $\mathrm{AD}$ at elevations above $2500 \mathrm{~m}$ a.s.l. exist in developing countries with well documented examples from the Andes: In Peru at $3300 \mathrm{~m}$ a.s.l., tubular digesters have operated at psychrophilic conditions in households with 3-5 members produced $0.5 \mathrm{Nm}^{3}$ biogas $\left(0.1-0.2 \mathrm{Nm}^{3}\right.$ per capita and day) with a methane content of over $60 \%$ from 9 to $12 \mathrm{~kg}$ fresh cow dung per day, which covered $40-60 \%$ of cooking fuel needs [12,13]. Of 261,000 small-scale AD installed through BSP-Nepal until 2012, less than 1\% was installed in remote hilly regions and the mountain ecological belt above $2500 \mathrm{~m}$ a.s.l. [6], where poverty is severe, access to energy sources most precarious and dependence on firewood mostly $100 \%$. We found no study of AD with comparable conditions in terms of living standards and elevation. In this study we compare firewood consumption with biogas potential from organic substrates in a community at $3150 \mathrm{~m}$ a.s.l. Results are useful for the planning of pilot anaerobic digesters as component of sustainable community development and provide insights into current firewood use patterns in one of the poorest regions of the world.

\section{Methods}

\subsection{Study area}

The research was conducted in the community Moharigaun $\left(29^{\circ} 20 / 06 \mathrm{~N}, 82^{\circ} 22 / 26 \mathrm{E}\right)$ at $3150 \mathrm{~m}$ a.s.l. in the remote north-east of Jumla District, where $>99 \%$ of households used firewood for cooking in 2011 [1]. Moharigaun can be accessed on foot from Jumla Bazar $20 \mathrm{~km}$ away and consisted of 39 families with 229 inhabitants in 2016. All inhabitants are subsistent farmers with very limited additional cash income from selling wood, goats and some forest fruits. The Nepalese/Swiss Non-Governmental Organisation Rural Integrated Development Services (RIDSNepal/RIDS-Switzerland) has been active in the community and region since 1996 with holistic community development projects including smokeless metal stoves (Fig. 1A), pit latrines as alternative to open defecation (Fig. 1C), solar photovoltaic for indoor lighting, drinking water tap stands and greenhouses (Fig. 1D). The long-term 


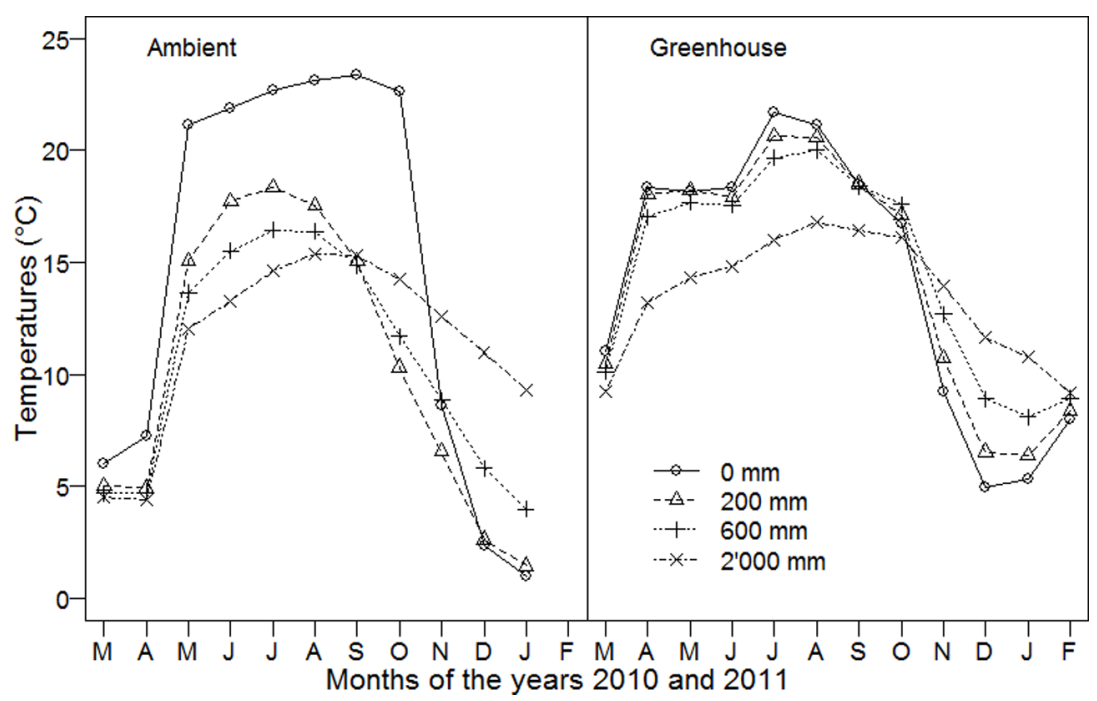

Fig. 2. Mean monthly temperatures outside (ambient) and inside greenhouse in Simikot, Humla, at $3000 \mathrm{~m}$ a.s.l. at different soil depths (0-2000 mm below ground), all (c) A. Zahnd.

trust of inhabitants to RIDS, greenhouses as potential AD locations with some thermal insulation (Fig. 2) and pit latrines as potential substrate source make Moharigaun favourable for this study.

\subsection{Baseline assessment of firewood use and organic waste occurrence}

Firewood use and organic substrates were assessed through two household surveys in five households (A-E, Fig. 3 inlet) over 7 days in spring (28 March to 3 April) and in winter (20-26 November) 2016. The households were selected after a survey of all 39 households in March 2016 as representative examples for number of household members, firewood use and animals owned. During the surveys, a sufficient amount of firewood was left each morning at every household. Each succeeding morning, remaining firewood was weighed using a spring balance to calculate daily consumption. Firewood energy content was estimated assuming a wood net calorific value of $12 \mathrm{MJ} \mathrm{kg}^{-1}$ at $30 \%$ moisture [14]. Organic substrate survey included cow, horse and sheep dung collected in overnight shelters where animals are kept overnight and did not include droppings on pastures. Gardening and agricultural residues were not considered as they are fed to animals and are not deemed available for biogas production.

\subsection{Biochemical methane potential tests, analytical methods and potential estimation}

Substrate samples were collected during spring and winter surveys. BMP tests were adapted from procedures described by Owen et al. [15] and Wellinger et al. [5] and carried out at Kathmandu University (KU) at $1474 \mathrm{~m}$ a.s.l., and also in Moharigaun at $3150 \mathrm{~m}$ a.s.l. under less controlable conditions, with substrates collected in spring. Temperatures were maintained by water baths in insulated boxes with manual temperature regulation twice per day due to frequent power cuts at KU and no electricity in Moharigaun. This led to temperature variations: $36 \pm 3{ }^{\circ} \mathrm{C}$ (mean \pm s.d.) at KU and $35 \pm 4^{\circ} \mathrm{C}$ in Moharigaun, measured before temperature regulation. BMPs were set up in triplicates in $125 \mathrm{~mL}$ vials filled with $85 \mathrm{~mL}$ substrate-inoculum mixtures with volatile solid (VS) ratios of 2:1 and capped with rubber stoppers. Triplicate controls with $85 \mathrm{~mL}$ inoculum were included in each setup. Biogas yield $(\mathrm{mL})$ over time was measured at least every third day using gas-tight graduated syringes inserted through the rubber stopper and allowing the piston to be pushed up by overpressure until equilibrated to atmospheric pressure. $\mathrm{CH}_{4}$ (vol\%) was measured one to two times during each BMP via gas chromatography (GC), for which gas samples were transported in gas tight vials to the National Environmental Engineering and Research Institute, Nagpur, India, as no GC was available at KU. Therefore, $\mathrm{CH}_{4}$ content presented here is only indicative. Inoculum biogas yield was measured in reference BMPs, standardized per unit VS and subtracted from other BMPs. Gas volumes were adjusted to standard temperature $\left(0^{\circ} \mathrm{C}\right)$ and pressure $(1013.15 \mathrm{hPa})$ and normalized per unit VS $\left(\mathrm{Nm}^{3} \mathrm{CH}_{4} \mathrm{~kg}_{\mathrm{VS}}{ }^{-1}\right)$. Total solids (TS) and VS were analysed before BMP setup using standard methods [16].

The mean daily biogas potential per substrate unit (human excrements or animal dung), household and capita were calculated according to formulas (1)-(3), respectively:

Mean daily biogas potential per substrate

$$
\text { unit and season : } \mathrm{UB}_{s, u}=\mathrm{AD}_{s, u} \times B_{u}
$$

Mean daily biogas potential per household and

$$
\text { season : } \mathrm{HB}_{s, h}=\sum_{u=1}^{n} \mathrm{AS}_{s, h, u} \times B_{u}
$$

Mean daily biogas potential per capita,

$$
\text { household and season : } \mathrm{CB}_{s, h}=\frac{\mathrm{HB}_{s, h}}{\mathrm{~N}_{s, h}}
$$

where $\mathrm{AD}_{s, u}$ is the mean accessible dung from overnight shelters or human excrements from pit latrines per season $s$ (spring and winter) and per substrate unit $u$ (humans or 


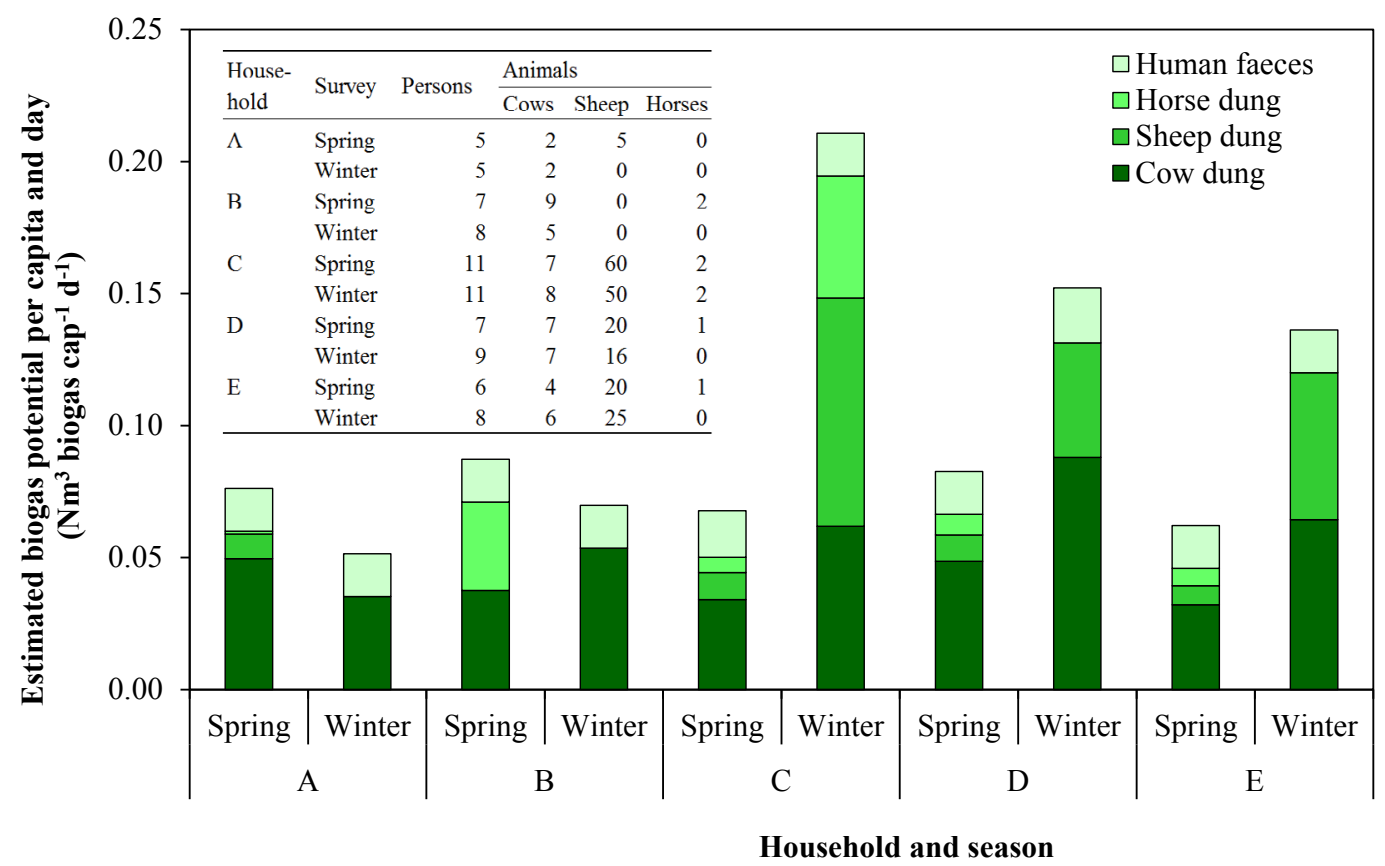

Fig. 3. Estimated daily biogas potential per capita and season $\left(\mathrm{Nm}^{3} \mathrm{cap}^{-1} \mathrm{~d}^{-1}\right)$ for surveyed households; inlet: household overview with mean number of persons and animals present during spring and winter survey.

cows, sheep and horses) in $\mathrm{kg}_{\mathrm{VS}}$ per day; $B_{u}$ is the biogas potential in $\mathrm{Nm}^{3} \mathrm{~kg}_{\mathrm{VS}}{ }^{-1}$ specific per substrate unit (only measured in spring); $\mathrm{AD}_{s, h, u}$ is $\mathrm{AD}_{s, u}$ specific for each household; and $N_{s, h}$ is the number of household members in household $h$ during season $s$.

\section{Results}

\subsection{Firewood use and biogas yield of organic substrates}

The 39 households of Moharigaun have on average six household members (2-12) with four cows (8\% of households in Moharigaun have none, $66 \%$ have up to $5,23 \%$ have $6-10$, and $3 \%$ more), 14 sheep ( $18 \%$ none, $31 \%$ up to $10,44 \% 10-30$, and $7 \%$ more) and one horse ( $67 \%$ none, $13 \%$ one, $20 \%$ two). These variations are reflected in the selection of five surveyed households (Fig. 3, inlet), with households D and E closest to "average" households.

Cooking, water boiling, room heating and alcohol production were mentioned to require firewood in all households. Cooking is done three to five times daily and during cold temperatures a small fire is left burning for room heating. In the surveyed households, mean firewood consumption per capita (cap) and day (d) was $2.1 \mathrm{~kg} \mathrm{cap}^{-1}$ $\mathrm{d}^{-1}$ in spring and $2.3 \mathrm{~kg} \mathrm{cap}^{-1} \mathrm{~d}^{-1}$ in winter, equivalent to ca. $25 \mathrm{MJ}$ and $28 \mathrm{MJ}$, respectively [14], mainly using Himalayan Pine (Pinus wallichiana). Easily collectable dung (wet weight per substrate unit and day, $\mathrm{kg}_{\mathrm{ww}} \mathrm{u}^{-1} \mathrm{~d}^{-1}$ ) from overnight shelters was for cows $1.62 \mathrm{~kg}_{\mathrm{ww}} \mathrm{u}^{-1} \mathrm{~d}^{-1}$ and $2.41 \mathrm{~kg}_{\mathrm{ww}} \mathrm{u}^{-1} \mathrm{~d}^{-1}$ in spring and winter $(+50 \%$ compared to spring); for sheep $0.03 \mathrm{~kg}_{\mathrm{ww}} \mathrm{u}^{-1} \mathrm{~d}^{-1}$ and $0.09 \mathrm{~kg}_{\mathrm{ww}} \mathrm{u}^{-1} \mathrm{~d}^{-1}$ $(+200 \%)$; and for horses $1.47 \mathrm{~kg}_{\mathrm{ww}} \mathrm{u}^{-1} \mathrm{~d}^{-1}$ and $2.95 \mathrm{~kg}_{\mathrm{ww}}$ $\mathrm{u}^{-1} \mathrm{~d}^{-1}(+100 \%)$. Animals were kept close to households in winter, presumably explaining these differences. VS contents of organic substrates (VS, percent of wet weight, $\%_{\mathrm{ww}}$ ) were similar between spring and winter for cow dung

$\left(20 \%_{\mathrm{ww}}\right.$ and $18 \%_{\mathrm{ww}}$, respectively), sheep dung (44\% $\%_{\mathrm{ww}}$ and $\left.57 \%_{\mathrm{ww}}\right)$ and human excrements $\left(23 \%_{\mathrm{ww}}\right.$ and $25 \%$ ww $)$. VS of horse dung was lower in spring $\left(18 \%_{\mathrm{ww}}\right)$ compared to winter $\left(33 \%_{\mathrm{ww}}\right)$. Biogas yield and methane content per unit VS ( \pm s.d., $n=2-3$ ) measured at $\mathrm{KU}\left(\right.$ at $\left.36^{\circ} \mathrm{C}\right)$ and Moharigaun (at $35^{\circ} \mathrm{C}$ ), respectively, was $0.21 \pm 0.02$ and $0.21 \pm 0.03 \mathrm{Nm}^{3}$ $\mathrm{kg}_{\mathrm{VS}}{ }^{-1}$ for cow dung, $0.36 \pm 0.04$ and $0.01 \pm 0.01 \mathrm{Nm}^{3} \mathrm{~kg}_{\mathrm{Vs}}{ }^{-1}$ for sheep dung, $0.26 \pm 0.09$ and $0.16 \pm 0.04 \mathrm{Nm}^{3} \mathrm{~kg}_{\mathrm{vs}}{ }^{-1}$ for horse dung, and $0.31 \pm 0.25$ and $0.08 \pm 0.01 \mathrm{Nm}^{3} \mathrm{~kg}_{\mathrm{VS}}{ }^{-1}$ for human excrements over 31 days (Tab. 1, only KU values shown).

Per cow, sheep, horse and person a daily biogas potential $\left(\mathrm{UB}_{s, u}\right.$, formula (1)) of $0.07 \mathrm{Nm}^{3}, 0.01 \mathrm{Nm}^{3}$, $0.07 \mathrm{Nm}^{3}$ and $0.01 \mathrm{Nm}^{3}$ can be expected in spring and $0.09 \mathrm{Nm}^{3}, 0.02 \mathrm{Nm}^{3}, 0.25 \mathrm{Nm}^{3}$ and $0.02 \mathrm{Nm}^{3}$ in winter due to differences in dung availability in overnight shelters next to houses (Tab. 1). Overall dung produced per animal and day is higher, as droppings on pastures are not included here. Indicative $\mathrm{CH}_{4}$ content measured once to twice for each BMP varied between 35\% and 60\% depending on substrate (Tab. 1) and only BMP results conducted at KU were included in subsequent calculations.

\subsection{Biogas potential per capita and household}

From results above, biogas potential per capita, day and season can be estimated for the five representative households $\left(\mathrm{CB}_{s, h}\right.$, formula (3)), which depends on the number of people in the household as well as types and 
Table 1. Accessible dung collected from overnight shelters (wet weight per substrate unit and day, $\mathrm{kg}_{\mathrm{ww}} \mathrm{u}^{-1} \mathrm{~d}^{-1}$ ), difference in dung collected in winter compared to spring (\%, bold), physical characterization (TS and VS, both $\%_{\mathrm{ww}}$ ), biogas generation based on BMPs at $\mathrm{KU}\left(\mathrm{Nm}^{3} \mathrm{~kg}_{\mathrm{VS}}{ }^{-1}\right.$ and $\mathrm{Nm}^{3} \mathrm{u}^{-1} \mathrm{~d}^{-1}, n=3$ per substrate) and indicative $\mathrm{CH}_{4}$ ranges.

\begin{tabular}{|c|c|c|c|c|c|c|c|c|c|}
\hline \multirow[t]{2}{*}{ Substrate } & \multirow[t]{2}{*}{ Season } & \multirow{2}{*}{$\begin{array}{l}\text { Dung per unit } \\
\left(\operatorname{kg}_{\mathrm{ww}} \mathrm{u}^{-1} \mathrm{~d}^{-1}\right)\end{array}$} & & \multicolumn{3}{|c|}{ Characterization } & \multicolumn{3}{|c|}{ Biogas generation } \\
\hline & & & & $\mathrm{TS}\left(\%_{\mathrm{ww}}\right)$ & $\operatorname{VS}\left(\%_{\mathrm{ww}}\right)$ & $n$ & $\mathrm{Nm}^{3} \mathrm{~kg}_{\mathrm{VS}}{ }^{-1} \mathrm{~d}^{-1}$ & $\mathrm{Nm}^{3} \mathrm{u}^{-1} \mathrm{~d}^{-1}$ & $\mathrm{CH}_{4}(\%)$ \\
\hline \multirow{3}{*}{ Cow dung } & Spring & $1.62 \pm 1.01$ & & $23 \pm 9$ & $20 \pm 4$ & 3 & $0.21 \pm 0.02^{\mathrm{a}}$ & $0.07 \pm 0.08$ & \multirow[b]{2}{*}{$40-60$} \\
\hline & Winter & $2.41 \pm 0.07$ & $+50 \%$ & $25 \pm 11$ & $18 \pm 5$ & 5 & & $0.09 \pm 0.01$ & \\
\hline & Spring & $0.03 \pm 0.03$ & & $54 \pm 7$ & $44 \pm 4$ & 3 & $0.36 \pm 0.04^{\mathrm{a}}$ & $0.01 \pm 0.00$ & \multirow[b]{2}{*}{$35-48$} \\
\hline Sheep dung & Winter & $0.09 \pm 0.01$ & $+\mathbf{2 0 0 \%}$ & $69 \pm 2$ & $57 \pm 2$ & 5 & & $0.02 \pm 0.00$ & \\
\hline \multirow[b]{2}{*}{ Horse dung } & Spring & $1.47 \pm 0.99$ & & $23 \pm 4$ & $18 \pm 4$ & 4 & $0.26 \pm 0.09$ & $0.07 \pm 0.36$ & \multirow[b]{2}{*}{$37-51$} \\
\hline & Winter & $2.95 \pm 0.04$ & $+100 \%$ & $36 \pm 5$ & $33 \pm 3$ & 5 & & $0.25 \pm 0.01$ & \\
\hline Human excrements & $\begin{array}{l}\text { Spring } \\
\text { Winter }\end{array}$ & Not sampled & & $\begin{array}{l}26 \pm 1 \\
28 \pm 2\end{array}$ & $\begin{array}{l}23 \pm 1 \\
25 \pm 1\end{array}$ & $\begin{array}{l}4 \\
5\end{array}$ & $0.31 \pm 0.25$ & $\begin{array}{l}0.02^{\mathrm{b}} \\
0.02^{\mathrm{b}}\end{array}$ & $45-52$ \\
\hline
\end{tabular}

a Only two of three samples considered, third sample $<10 \%$ biogas generation compared to other two.

b Assuming $0.3 \mathrm{~kg}_{\mathrm{ww}}$ per unit (person) and day, based on three samples from RIDS staff and not Moharigaun residents.

number of animals (Fig. 3). Depending on household and season, between 0.05 and $0.21 \mathrm{Nm}^{3}$ biogas cap ${ }^{-1} \mathrm{~d}^{-1}$ can be expected, with average values of $0.08 \mathrm{Nm}^{3} \mathrm{cap}^{-1} \mathrm{~d}^{-1}$ in spring and $0.12 \mathrm{Nm}^{3} \mathrm{cap}^{-1} \mathrm{~d}^{-1}$ in winter. Cow dung on average contributes $55 \%$ of the biogas potential $(29-77 \%$, depending on household and season). Sheep dung contribution varies between seasons: in households $\mathrm{C}-\mathrm{E}$ sheep contribute $12-15 \%$ of biogas potential in spring and $29-41 \%$ in winter, however in household A sheep only contribute in spring. Horse dung contribution is only significant in households B (spring, winter: $38 \%, 0 \%$ ) and C $(8 \%, 22 \%)$. Human excrements on average make up $20 \%$ of the biogas potential $(8-31 \%)$. For an average household, cow, sheep and horse dung are expected to yield $0.05,0.02$ and $0.01 \mathrm{Nm}^{3} \mathrm{cap}^{-1} \mathrm{~d}^{-1}$, respectively, while human excrements contribute $0.02 \mathrm{Nm}^{3} \mathrm{cap}^{-1} \mathrm{~d}^{-1}$.

\section{Discussion}

\subsection{Potential biogas contribution to energy needs and firewood substitution}

People in remote mountain villages in Nepal belong to the poorest in the world with nothing to spare. Most organic substrates already have alternative uses: kitchen and gardening residues are fed to animals and dung from overnight shelters is used as organic fertilizer. While animal feeding should not be rivalled, AD slurry retains fertilizer properties and the use of animal dung for $\mathrm{AD}$ poses thus no resource competition and may provide economic benefits from crop production [13]. Cow dung is the most important animal substrate as it is available in almost all households and on average contributes almost $60 \%$ of the per capita biogas potential. Sheep dung is not available in every household and varies with season with higher substrate availability in overnight shelters during winter in most cases, when animals are kept close to houses and are not on remote pastures. Human excrements are available in pit latrines in Moharigaun and on average contribute $20 \%$ of the per capita biogas potential. Careful public health considerations are necessary however, especially if the slurry is used as organic fertilizer [9]. Biogas yield per unit VS and methane content were in this study at a lower ranges of published values, which can probably be related to challenging experimental conditions with frequent power cuts and transportation of samples to India for GC analyses. Results presented here are nevertheless useful as a first indication of potential AD applicability and to plan pilot digesters for a remote location where no such data exist. Realistic firewood substitution potential cannot be directly derived from BMP studies alone and in situ pilot-studies are required. Biogas requirements to cover cooking needs have been estimated at ca. $0.2-0.3 \mathrm{Nm}^{3}$ cap $^{-1} \mathrm{~d}^{-1}$ for households with six persons in Nepal [17] and between 0.1 and $0.3 \mathrm{Nm}^{3} \mathrm{cap}^{-1} \mathrm{~d}^{-1}$ for households with three to five members in the Bolivian Andes above $3300 \mathrm{~m}$ a.s.l. [12], of which - based on Fig. 3 and assuming $0.2 \mathrm{Nm}^{3} \mathrm{cap}^{-1} \mathrm{~d}^{-1}$ biogas requirement - on average about $60 \%$ (26-105\% depending on season and household) could be generated from local accessible substrates. In the typical household D between $40 \%$ (spring) and $75 \%$ (winter) of cooking energy needs could be covered under these assumptions.

Firewood savings are more difficult to quantify and depend on the efficiency of wood and biogas stoves, but can be roughly estimated based on the energy content of $\mathrm{CH}_{4}$ (ca. $38 \mathrm{MJ} \mathrm{Nm}^{-3} \mathrm{CH}_{4}[5]$ ) and firewood (ca. $12 \mathrm{MJ} \mathrm{kg}^{-1}$ at $30 \%$ moisture [14]). Based on a mean biogas potential of $0.08 \mathrm{Nm}^{3} \mathrm{cap}^{-1} \mathrm{~d}^{-1}$ in spring and $0.12 \mathrm{Nm}^{3} \mathrm{cap}^{-1} \mathrm{~d}^{-1}$ in winter, and assuming a $\mathrm{CH}_{4}$ content of $60 \%$ in biogas, about $0.15 \mathrm{~kg} \mathrm{cap}^{-1} \mathrm{~d}^{-1}$ firewood $\left(0.12-0.17 \mathrm{~kg} \mathrm{cap}^{-1} \mathrm{~d}^{-1}\right.$ depending on household) could be substituted in spring and $0.21 \mathrm{~kg} \mathrm{cap}^{-1} \mathrm{~d}^{-1} \quad\left(0.10-0.40 \mathrm{~kg} \mathrm{cap}^{-1} \mathrm{~d}^{-1}\right)$ in winter, against a firewood usage of $2.1 \mathrm{~kg} \mathrm{cap}^{-1} \mathrm{~d}^{-1}$ in spring and $2.3 \mathrm{~kg} \mathrm{cap}^{-1} \mathrm{~d}^{-1}$ in winter.

\subsection{Recommendations for pilot installations}

Results presented here show that $\mathrm{AD}$ could play a role in decentralized, diversified energy supply in remote Nepalese communities of the mountain ecological belt. Pilot digesters should be targeted for households with year- 
around reliable substrate availability and representativeness for other households. These conditions are met by household D (Fig. 3), which has seven cows $(23 \%$ of households have $6-10$ cows), about 20 sheep (75\% of households have one to 30 sheep) and one horse (33\% of households have 1-2 horses). Household $\mathrm{C}$ is rather special as this is the only household with more than 50 sheep. Formula (1) with parameters in Table 1 can be used for a preliminary estimation of the total biogas potential of communities and households in Nepal at a similar elevation and level of development, based on number of inhabitants and animals held.

Here we only present results from BMPs conducted at mesophilic conditions at ca. $36^{\circ} \mathrm{C}$ and results from ongoing BMP tests at lower temperature ranges are expected to contribute to further findings and understanding. $\mathrm{AD}$ is in principle possible even close to $0{ }^{\circ} \mathrm{C}$ but not considered practical for biogas production below $15^{\circ} \mathrm{C}$, which is still the case during ca. 5 winter months in greenhouses even $20 \mathrm{~cm}$ below soil (Fig. 2). At least during those times supplementary heating would be required e.g. from thermal solar energy, symbiosis with currently planned picohydropower-plants $(6 \mathrm{~kW})$ making use of surplus electricity production during night time as well as hot charging, i.e. heating of substrates. Thermal digester insulation can be achieved through optimal digester placement (underground in greenhouses or under animal shelters) as well as insulation materials including locally available sawdust, birch tree bark or pine tree needles. AD should thus not be considered a stand-alone solution and integration into sustainable community development with frequent technical assistance is required. Under these conditions, we expect that $\mathrm{AD}$ could proof successful in sustainably improving energy supply even in these remote and deprived conditions.

We are thankful for help we received from undergraduate students at Kathmandu University in Dhulikel, Nepal, staff of RIDS-Nepal Jumla field team as well as the support of the people and families of Moharigaun and surrounding villages. We acknowledge financial support received through the Seed Money Programme by ETH Global Switzerland.

\section{References}

1. Government of Nepal, National Population and Housing Census 2011 (National Report) (Central Bureau of Statistics, National Planning Commission Secretariat, Government of Nepal, Kathmandu, 2012)
2. B.G. Naylor, Changing Well-Being and Livelihoods: An Examination of the Impacts of Smokeless Metal Stoves on Individuals and Communities in Humla, Nepal, B. Sc. Thesis (Reading University, Reading, UK, 2012)

3. L.P. Naeher, M. Brauer, M. Lipsett, J.T. Zelikoff, C.D. Simpson, J.Q. Koenig, K.R. Smith, Woodsmoke health effects: a review, Inhalat. Toxicol. 19, 67 (2007)

4. Government of Nepal, National Indoor Air Quality Standards and Implementation Guideline (Ministry of Environment, Science and Technology, Government of Nepal, Kathmandu, 2009)

5. A. Wellinger, J.D. Murphy, D. Baxter, The Biogas Handbook: Science, Production and Applications (Elsevier, Cambridge, UK, 2013)

6. BSP-Nepal, BSP 2011/12, Biogas Support ProgrammeNepal, Lalipur, Nepal, 2012

7. P.C. Ghimire, SNV supported domestic biogas programmes in Asia and Africa, Renew. Energy 49, 90 (2013)

8. G.V. Rupf, P.A. Bahri, K. de Boer, M.P. McHenry, Barriers and opportunities of biogas dissemination in Sub-Saharan Africa and lessons learned from Rwanda, Tanzania, China, India, and Nepal, Renew. Sustain. Energy Rev. 52, 468 (2015)

9. R. Nkoa, Agricultural benefits and environmental risks of soil fertilization with anaerobic digestates: a review, Agron. Sustain. Dev. 34, 473 (2014)

10. T. Bond, M.R. Templeton, Energy for sustainable development. History and future of domestic biogas plants in the developing world, Energy Sustain. Dev. 15, 347 (2011)

11. D. Kashyap, K. Dadhich, S. Sharma, Biomethanation under psychrophilic conditions, Waste Manag. 30, 2490 (2010)

12. I. Ferrer, M. Garfí, E. Uggetti, L. Ferrer-Martí, A. Calderon, E. Velo, Biogas production in low-cost household digesters at the Peruvian Andes, Biomass Bioenergy 35, 1668 (2011)

13. M. Garfí, L. Ferrer-Martí, E. Velo, I. Ferrer, Evaluating benefits of low-cost household digesters for rural Andean communities, Renew. Sustain. Energy Rev. 16, 575 (2011)

14. FAO, Wood Fuels Handbook (Food and Agriculture Organization of the United Nations, Rome, 2015)

15. W.F. Owen, D.C. Stuckey, J.B. Healy, Bioassay for monitoring biochemical methane potential and anaerobic toxicity, Water Res. 13, 485 (1979)

16. APHA, AWWA, WEF, Standard Methods for the Examination of Water and Wastewater, edited by A. Eaton, L. Clesceri, E. Rice, A. Greenberg, M. Franson (American Public Health Association, American Water Works Association, Water Environmental Federation, Washington, DC, 2005)

17. FAO, CMS, Biogas Technology: A Training Manual for Extension (Food and Agriculture Organization of the United Nations and Consolidated Management Services Nepal, Kathmandu, 1996)

Cite this article as: Thomas Gross, Alex Zahnd, Suman Adhikari, Abhishek Kaphre, Subodh Sharma, Bivek Baral, Sunil Kumar, Christoph Hugi, Potential of biogas production to reduce firewood consumption in remote high-elevation Himalayan communities in Nepal, Renew. Energy Environ. Sustain. 2, 8 (2017) 